Arch. histol. jap., Vol. 41, No. 3 (1978)

p. $195-204$

Department of Anatomy (Prof. T. ITo), Hokkaido University School of Medicine, Sapporo, Japan

\title{
Fine Structure of the Dome in Peyer's Patches of Mice*
}

\author{
Kazuhiro ABE and Takashi ITo
}

Received October 22, 1977

\begin{abstract}
Summary. The dome area of Peyer's patches in adult mice was studied by electron microscopy. The cellular constituents of the area are lymphocytes, plasma cells, macrophages and reticular cells. Macrophages are filled with numerous lysosomal bodies containing dead lymphocytes or plasma cells. The epithelium covering the dome is infiltrated with numerous lymphocytes, a few plasma cells and macrophages. These wandering cells first are found intercellularly but later appear to penetrate into the epithelial cell cytoplasm just beneath the cell apex. The epithelial cells containing the wandering cells in the supranuclear portion protrude into the intestinal lumen, and their microvilli are short and scanty. The epithelial cells covering the dome of ten have inclusion bodies containing dead wandering cells. Such modification of the epithelial cells may be related to the presence of underlying follicles.

The results suggest that the dome including the covering epithelium is a site in which antigens from the intestinal lumen might come in direct contact with lymphocytes or other wandering cells.
\end{abstract}

The thymus and the avian bursa of Fabricius have been considered as the central lymphatic tissue which provides an epithelial microenvironment, where stem cells derived from the bone marrow differentiate into immunocompetent lymphocytes which are seeded into peripheral lymphatic tissues (GREAvEs et al., 1973). In mammals which lack the bursa, gut-associated lymphatic tissues including the tonsil, Peyer's patches and appendix have been considered as the possible bursa-equivalent (Cooper et al., 1966; Fichtelius, 1966; Craig and Cebra, 1975). However, gut-associated lymphatic tissues are different from the central lymphatic tissue in that they serve as the site of antibody-production (CoOPER and Turner, 1967; Müller-Schoop and Good, 1975) and that lymphopoiesis is dependent on antigenic stimulation (PEREY and GooD, 1968). In our previous papers (ABE and ITO, 1977, 1978), Peyer's patches that represent the major gut-associated lymphatic tissue in the mouse have been examined by qualitative and quantitative morphologic methods. The patch was histologically divided into four portions; germinal center, follicular area, parafollicular area and dome area. The germinal center, follicular area and parafollicular area of the patch were thought morphologically and functionally to correspond to similar portions of peripheral lymphatic tissues such as the spleen and lymph nodes (ABE and Iто, 1972, 1977, 1978). However, the dome area appeared to be specific to the Peyer's patch in structure. In particular, the intimate relationship of lymphocytes to the overlying epithelium suggested that the dome might resemble the central lymphatic tissue and that the dome might serve as the bursa-equivalent as proposed by Blythman and Waksman (1973) and Waksman et al. (1973). In this study we

* This study was supported by grants from the Ministry of Education, 1976 (No. 112114, 167001). 
undertook to examine the fine structure of the dome by electron microscopy for better understanding of the nature of this specialized area in the Peyer's patch.

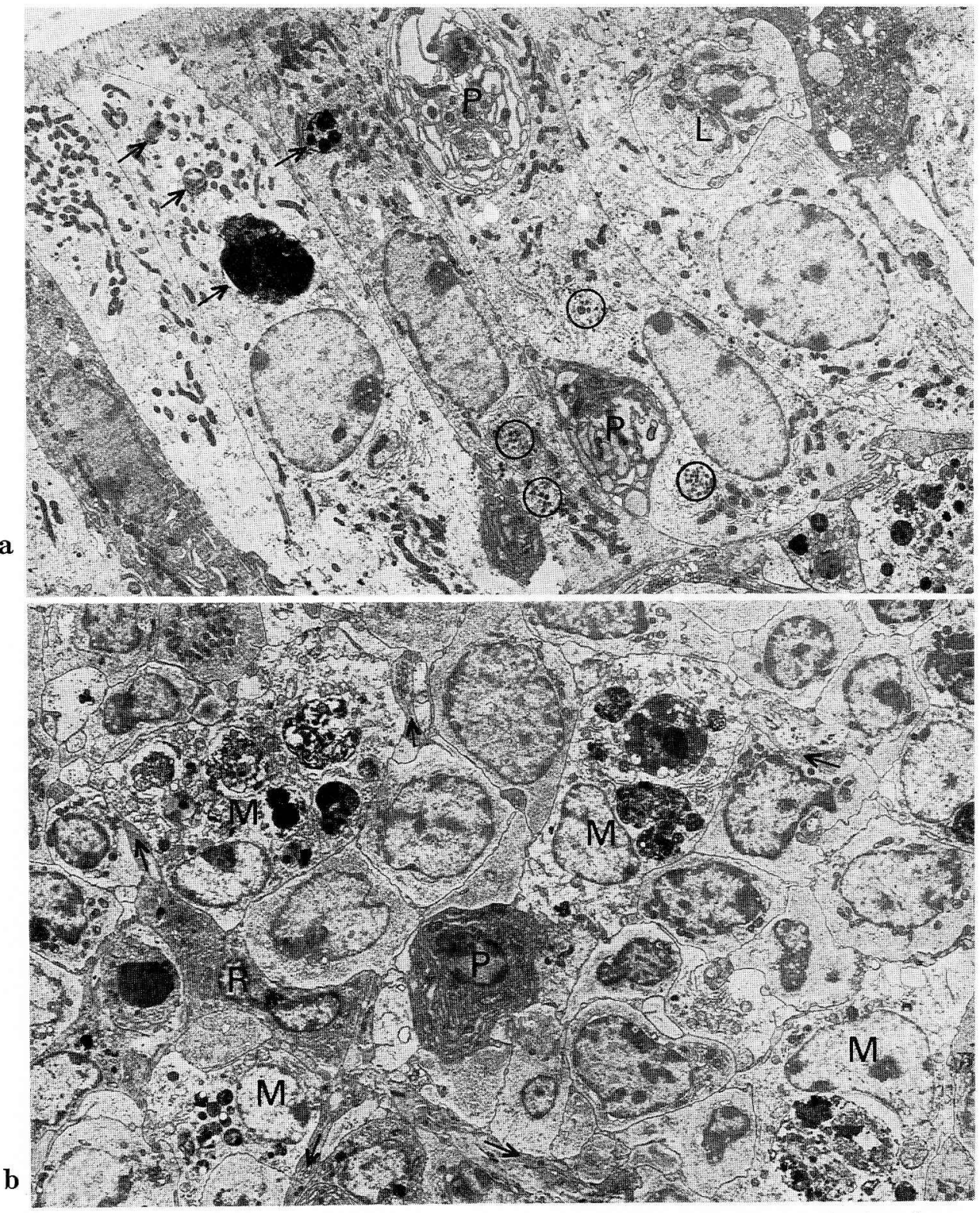

Fig. 1. a. Epithelium covering the dome is infiltrated with plasma cells $(P)$ and a lymphocyte $(L)$. The epithelial cells contain inclusions (arrows) in the supranuclear portion and accumulations of granules (circles). $\times 2,800$. b. The dome area is populated with lymphocytes, macrophages $(M)$, plasma cells $(P)$ and reticular cells $(R)$. Macrophages contain numerous lysosomal inclusions. Reticular cells have elongated cytoplasmic processes (arrows). $\times 2,800$ 


\section{Materials and Methods}

Peyer's patches from ten dd-mice of both sexes at 50 to 60 days of age were fixed in $5 \%$ formol in $0.5 \mathrm{M}$-phosphate buffer ( $\mathrm{pH} 7.5$ ) containing 1.5\% sucrose for 2 days at $4^{\circ} \mathrm{C}$, postfixed in $2 \%$ osmium tetroxide in the same buffer for $1.5 \mathrm{hrs}$ and embedded in Epon. Ultrathin sections were stained doubly with uranyl acetate and lead citrate and examined by electron microscopy.

\section{Results}

The cellular constituents of the dome area are lymphocytes, plasma cells, macrophages and reticular cells (Fig. 1b). Lymphocytes are varied in size, but the majority of them are small lymphocytes and lymphocytes having slightly larger nuclei than these of typical small lymphocytes. Both types of lymphocytes are generally similar in ultrastructural feature to lymphocytes seen in peripheral lymphatic tissues (ABE and Iто, 1970; AвE et al., 1973). Plasma cells are mainly mature forms with abundant rough endoplasmic reticulum, but a few plasma cells are relatively immature. Macrophages are filled with numerous membrane-bounded lysosomal bodies varying in size and appearance (Fig. Ib). Degenerated lymphocytes or plasma cells are occasionally contained within the membrane-bounded bodies of macrophages (Fig. 2). Reticular cells have elongated cytoplasmic processes with bundles of filaments running along the cell surface (Fig. 1b). Under the covering epithelium, attenuated processes of the reticular cells are in contact with the basal lamina (Fig. 1a). In the wide intercellular spaces around the cytoplasmic processes, collagen fibrils are often seen (Fig. 1b).
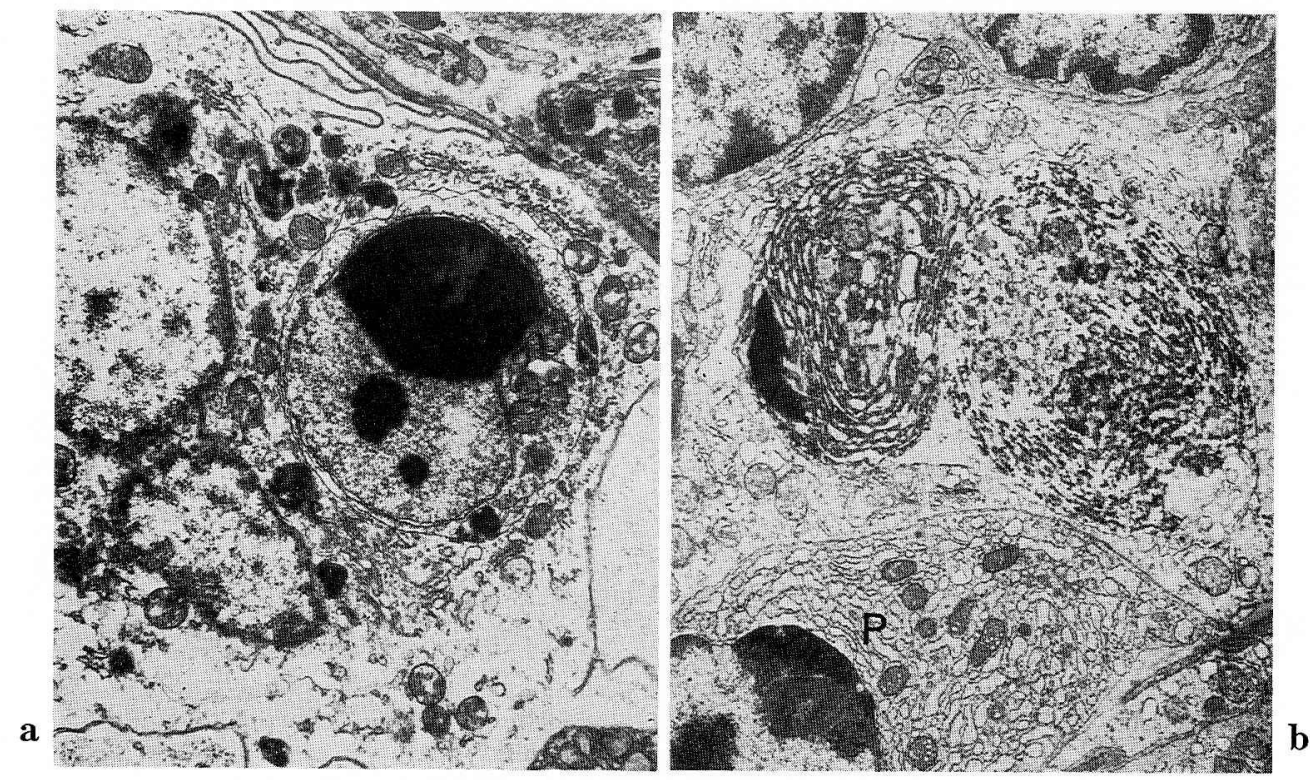

Fig. 2. Macrophages containing dead cells. a. A macrophage contains a degenerated lymphocyte. $\times 8,000$. b. Two degenerated plasma cells are engulfed in a macrophage. $P$ intact plasma cell. $\times 6,000$ 


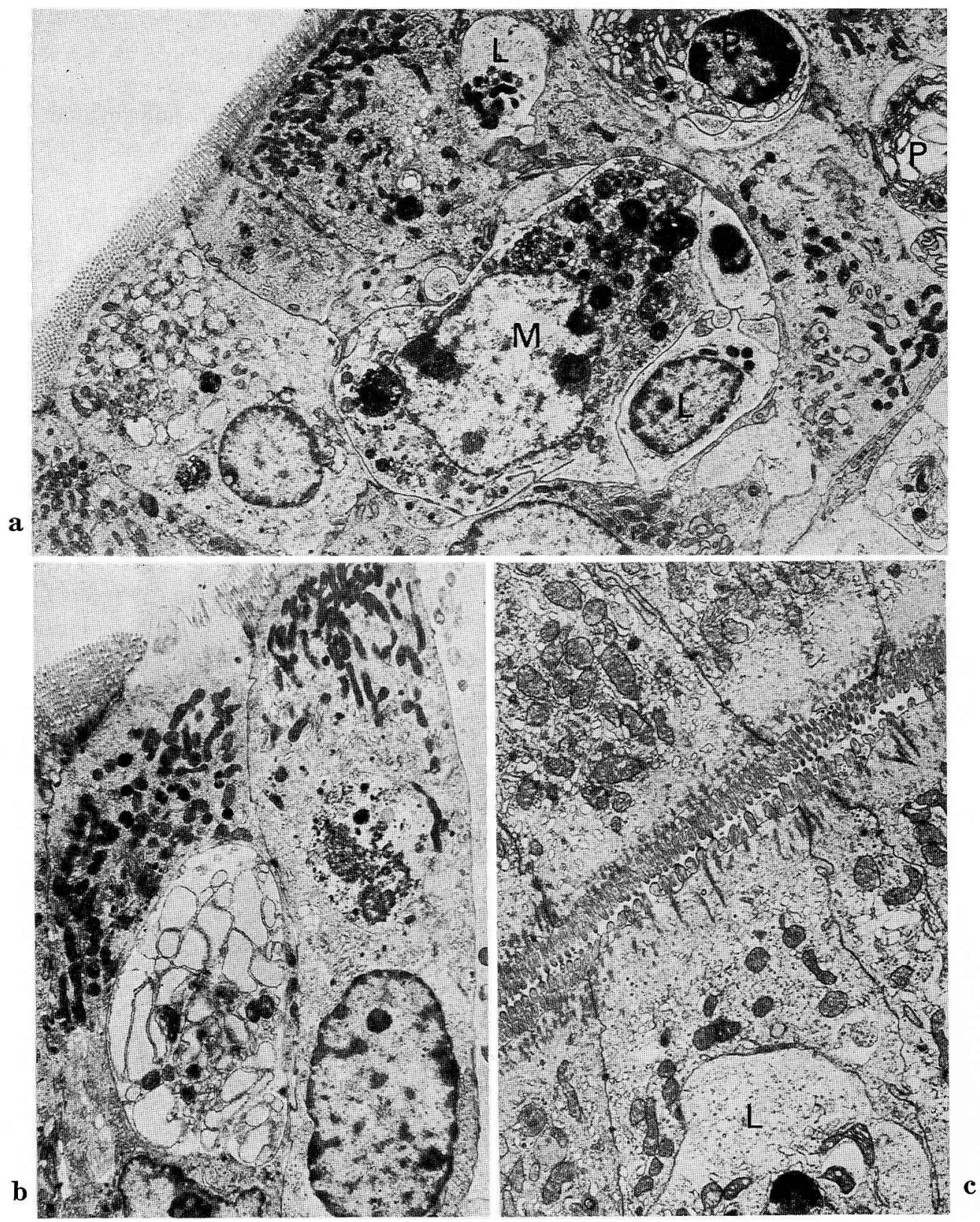

Fig. 3. Epithelium covering the dome. a. The epithelium is infiltrated with lymphocytes $(L)$, plasma cells $(P)$ and a macrophage $(M) . \times 3,500$. b. The luminal surface of the epithelial cell containing a plasma cell protrudes into the lumen. An epithelial cell (right) contains a large cytoplasmic inclusion. $\times 4,000$. c. Microvilli of the epithelial cells over the dome (lower) are irregular and shorter than over the villi (upper). They are especially less numerous on the epithelial cell containing a lymphocyte $(L) . \quad \times 6,500$ 
The intestinal epithelium covering the dome area is infiltrated with numerous lymphocytes (Fig. 1a, 3). The intraepithelial lymphocytes are typical small lymphocytes and lymphocytes with larger nuclei. Both types of intraepithelial lymphocytes have more abundant, lighter cytoplasm with scanty ribosome and are more irregular in nuclear and cellular contour than lymphocytes in the dome area. The intraepithelial lymphocytes are located, singly or in groups, between adjacent epi-

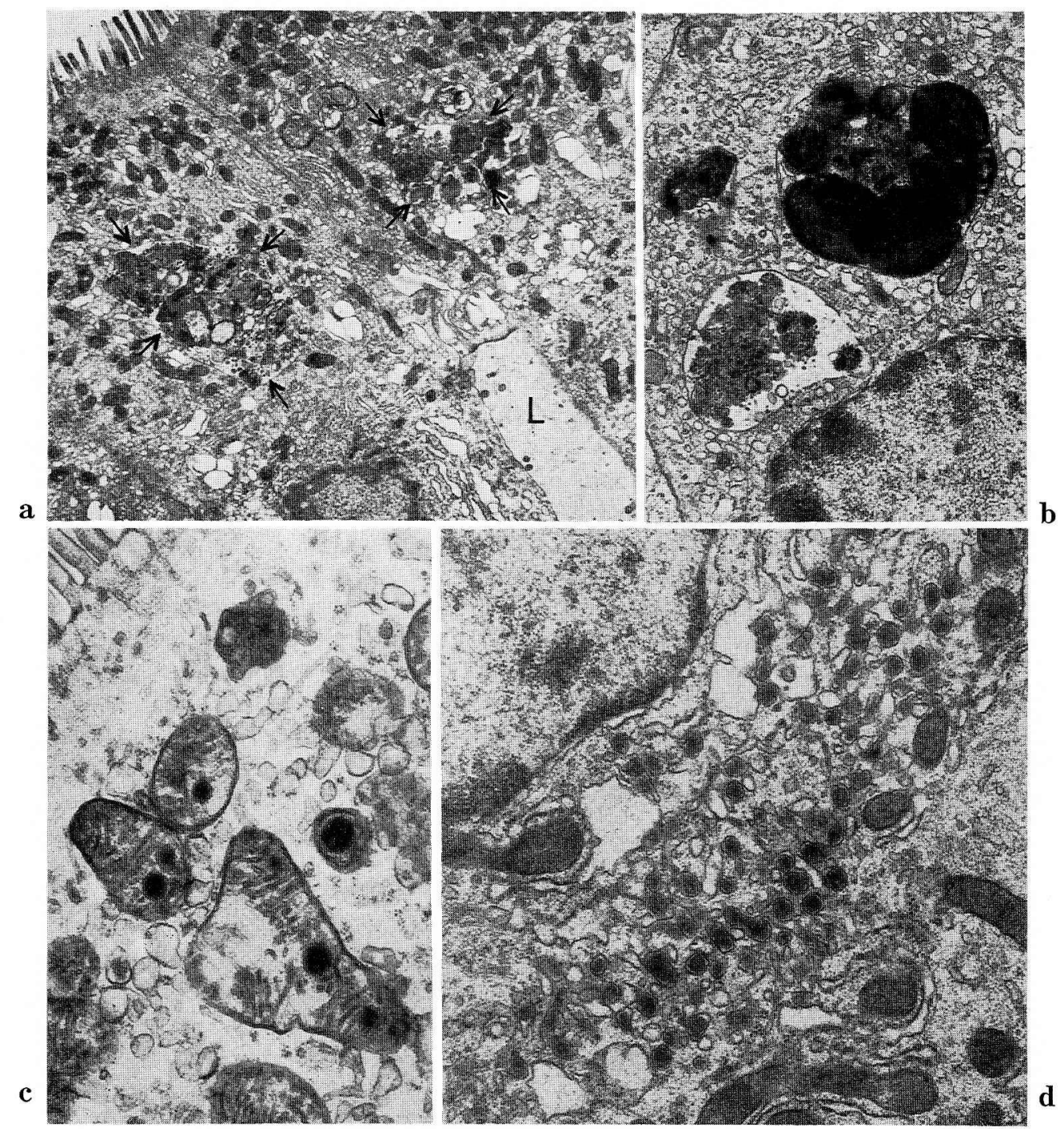

Fig. 4. Epithelial cells over the dome. a. Epithelial cells contain large inclusions (arrow) in the supranuclear cytoplasm. L Cytoplasm of an infiltrating lymphocyte. $\times 5,000$. b. Three intracytoplasmic inclusions showing varying appearane. $\times 10,000$. c. Mitochondria containing dense round inclusion within the cristae. $\times 18,000$ d. Accumulation of granules below the nucleus. A few granules are also found throughout the cytoplasm (Fig. 3b, 4). $\times 15,000$ 
thelial cells. The epithelial cells which appear as if containing lymphocytes in the cytoplasm near the luminal surface, protrude slightly into the lumen, and their microvilli are less numerous and shorter than those on the adjacent epithelial cells (Fig. 3c). Lymphocytes are often seen crossing the epithelial basal lamina. In addition to lymphocytes, plasma cells and macrophages are occasionally seen within the epithelium (Fig. 1a, 3).

Lymphocytes and plasma cells contained within the epithelium are fewer on the intervening villi than on the dome, and they are generally situated near the epithelial basal lamina.

The epithelial cells over the dome are low columnar, and their microvilli are shorter than those in the general epithelial cells (Fig. 1a, 3c). On close inspection, they are irregular in cellular outline, and vary in the position of nuclei due apparently to the presence of numerous intraepithelial wandering cells (Fig. 1a). Their mitochondria are smaller than those in the epithelial cells of the villi. Mitochondria in the epithelial cells over the dome occasionally contain dense round bodies, 50 to $150 \mathrm{~nm}$ in diameter, within the cristae (Fig. 4c). Such mitochondrial inclusions are not found in the epithelial cells of the villi. The epithelial cells overlying the dome often contain several membrane-bounded bodies in the cytoplasm, especially in the supranuclear portion (Fig. 1a, 3b, 4a, 4b). These intracytoplasmic bodies vary in size and are often as large as the nuclei. Their contents are various in density and composition. Myelin-like figures are occasionally contained (Fig. 4b). Degenerated lymphocytes or plasma cells are infrequently contained. In the epithelial cells of the villi, similar membrane-bounded bodies are rarely seen and, if present, they are small in size. In most of the intestinal epithelial cells, rounded or slightly elongated granules, $100-300 \mathrm{~nm}$ in diameter, with denser cores are distributed sparsely in the cytoplasm. In the epithelial cells of the dome, such granules are often accumulated in varying amounts below the nucleus (Fig. 4d). In the apical cytoplasm of the epithelial cell there are also vesicles of varying sizes. The vesicles, though variable in amount from cell to cell, do not show any significant difference in amount between the epithelial cells over the dome and those over the villi (Fig. 3c). Goblet cells and basal granulated cells with round, dense granules, $200-400 \mathrm{~nm}$ in diameter, rarely occur in the epithelium over the dome.

\section{Discussion}

The bursa of Fabricius is considered as a lympho-epithelial organ in which epithelial cells appear to induce differentiation of B-lymphocytes (GooD and GABRIELSEN, 1964; Greaves et al., 1973). Gut-associated lymphatic tissues such as Peyer's patches are also lympho-epithelial in nature, and the epithelial cells have been thought to exert the same influence on differentiation of lymphocytes as those of the avian bursa (Cooper et al., 1966, Fichtelius, 1966; CrAig and CEBrA, 1975). As reported in a previous paper (AвE and ITо, 1978), however, the epithelium over the dome of the Peyer's patch contains both T- and B-lymphocytes, and the proportions of intraepithelial T- and B-lymphocytes are similar to those in the total lymphocytes of the patch in which lymphocytes are mostly differentiated T-and B-lymphocytes as in the case of peripheral lymphatic tissues. Thus, intraepithelial lymphocytes are considered to have differentiated before immigration into the epithelium. Intraepithelial lymphocytes are more numerous on the lateral aspect of the dome (ABE and Iто, 
1977). On the lateral aspect of the dome, the intestinal epithelium lies close to the underlying follicle in which small lymphocytes are densely packed. As stated already, the intraepithelial wandering cells are similar in appearance to wandering cells in the subepithelial area of the dome. Thus, it is unlikely that undifferentiated lymphocytes migrate into the epithelium of the patch as seen in the central lymphatic tissue (GREAves et al., 1973). As reported in previous papers (ABE and ITo, 1977, 1978), the findings that almost half the intraepithelial 1ymphocytes are found at the supranuclear level of the epithelium and that they are sometimes seen leaving the apical surface of of the epithelium suggest that lymphocytes pass through the epithelium into the intestinal lumen. The route in which lymphocytes make way through the epithelium appears similar to that seen in the case of the endothelium of postcapillary venules in lymph nodes (Gowans and KNIGHT, 1964; ANDERson et al., 1976). Lymphocytes appear to cross the basal lamina and to migrate apicalwards between epithelial cells. Just beneath the apical surface of the epithelium, lymphocytes may penetrate into the cytoplasm of the epithelial cells, because the intercellular spaces are tightly closed with the junctional complex just beneath the cell surface. The apical cytoplasm that appears to be invaded with lymphocytes protrudes slightly into the lumen and its surface has few short microvilli. These features have been considered as representing epithelial cell specialization of the dome (OwEN and Jones, 1974; Owen, 1977).

As is generally known, the epithelium over the dome area is low columnar or cuboidal and contains few goblet cells (FAULK et al., 1970). This seems to imply that

D

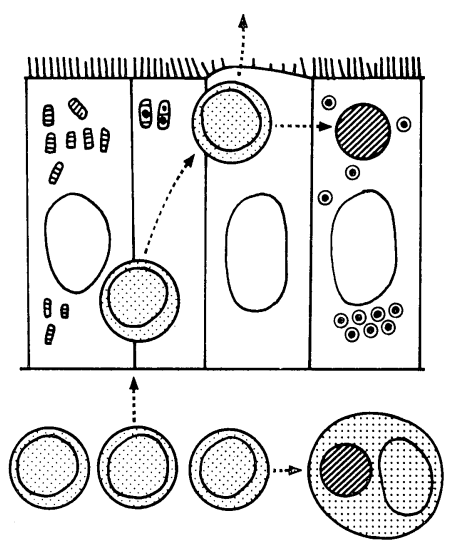

V

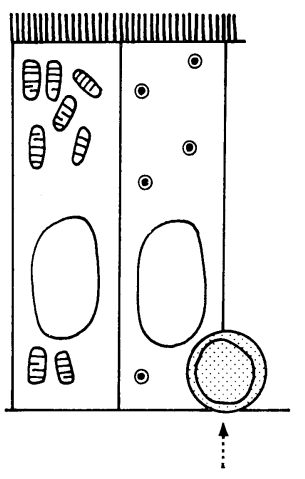

Fig. 5. Schematic diagram of the epithelium of the dome $(D)$ and villi $(V)$. The figures show the cell hight, length of microvilli, mitochondria and granules. Subepithelial wandering cells in the dome are also shown. Cells with small dots are lymphocytes. Shaded circles are debris of lymphocytes engulfed within the epithelial cell or macrophage (cell with large dots). The arrows indicate the possible migration pathway of lymphocytes or the fate of engulfed dead lymphocytes. 
antigenic substances may easily penetrate the epithelium from the lumen, as mucus secreted by goblet cells may serve as a barrier against the influx of antigenic substances. It has experimentally been demonstrated that India ink and ferritin, placed in the intestinal lumen, can be found within the apical vesicles of the epithelial cells over the dome (Bockman and Cooper, 1973). Thus the presence of such apical vesicles has been considered to indicate transport of antigens from the lumen into the Peyer's patch. As seen in the results, however, the apical vesicles are seen in the epithelial cells over the villi as well as over the dome. Thus it seems unlikely that the vesicles are related exclusively to the transport of antigenic materials in the dome epithelium.

As reported previously (ABE and ITO, 1977), the covering epithelial cells and macrophages in the dome area contain PAS-positive inclusions. These inclusions ultrastructurally appear to represent engulfed dying or dead lymphocytes or other wandering cells. Macrophages in the dome area have been demonstrated to contain numerous microorganisms (WAKSMAN et al., 1973).

Figure 5 summarizes that lymphocytes seem to invade the epithelium over the dome in response to antigens entering from the intestinal lumen and some of them appear to disintegrate within the epithelium. The dying or dead lymphocytes appear to be engulfed by macrophages and epithelial cells. Thus the dome including the covering epithelium is considered as a site in which antigens come in direct contact with lymphocytes or other wandering cells. The epithelial cells over the dome are similar in appearance to those over the villi, but their structural and functional features must be modified presumably by the presence of the underlying lymphatic follicle.

\section{マウスのパイェル板の円蓋域の微細構造}

$$
\text { 阿部和厚と伊藤隆 }
$$

成熟マウスのパイエル板の円蓋域を電子顕微鏡で観察した.

パイエル板の円蓋域の構成細胞はリンパ球，形質細胞，大食細胞，細網細胞である。大 食細胞はリンパ球と形質細胞の破壊片および多様な封入体で充満する。 円蓋域を被う上 皮内にはリンパ球，形質細胞，大食細胞が侵入する。これらの遊走細胞は上皮細胞の自由 表面に近づくと，上皮細胞の胞体内に侵入するようにみえる．遊走細胞を核上部に含む上 皮細胞の自由表面は，腸管内腔側へ突隆し，微䋐毛もまぼらになっている．また 円蓋域 学被う上皮細胞は，しばしば核上部に破壊された遊走細胞を含む封入体觉もつ。このよう な上皮細胞の構造は上皮下のリンパ小節の存在と関連しているようにみえる.

パイエル板の円蓋は，それを被う上皮も含めて，リンパ球その他の遊走細胞が腸管内 腔からの抗原に直接に接する反応部位と考えられる. 


\section{References}

Abe, K. and T. Ito: Fine structure of small lymphocytes in the thymus of the mouse: qualitative and quantitative analysis by electron microscopy. Z. Zellforsch. 110: 321-335 (1970). a single typhoid-paratyphoid vaccine injection in the mouse, with special reference to the topographic cellular changes in the early immune response. Arch. histol. jap. 34: 471-489 (1972).

: A qualitative and quantitative morphologic study of Peyer's patches of the mouse. Arch. histol. jap. 40: 407-420 (1977).

mouse after neonal thymectomy and hydrocortisone injection. Amer. J. Anat. 151: 227-238 (1978).

Abe, K., K. Sasaki and T. Ito: Comparative ultrastructure and cytometric analysis of small lymphocytes in haemopoietic organs of neonatal mice. J. Anat. 115: 393-406 (1973).

Anderson, N. D., A. O. Anderson and R. G. Wyllie: Specialized structure and metabolic activities of high endothelial venules in rat lymphatic tissues. Immunology 31: 455-473 (1976).

Blythman, H. E. and B. H. Waksman : Effect of irradiation and appendicostomy on appendix structure and responses of appendix cell to mitogens. J. Immunol. 111: 171-182 (1973).

Bockman, D. E. and M. D. Cooper : Pinocytosis by epithelium associated with lymphoid follicles in the bursa of Fabricius, appendix, and Peyer's patches. An electron microscopic study. Amer. J. Anat. 136: 455-478 (1973).

Cooper, M. D., D. Y. Perey, M. F. McKneally, A. E. Gabrielsen, D. E. R. Stutherland and R. A. Good: A mammalian equivalent of the avian bursa of Fabricius. Lancet 1:1388-1391 (1966).

Cooper, G. N. and K. Turner : Immunological response in rats following antigenic stimulation of Peyer's patches. I. Characteristics of the primary response. Aust. J. exp. Biol. med. Sci. 45: 363-378 (1967).

Craig, S. W. and J. J. Cebra: Rabbit Peyer's patches, appendix and popliteal lymph node Blymphocytes: a comparative analysis of their membrane immunogloblin components and plasma cell precursor potential. J. Immunol. 114: 492-502 (1975).

Faulk, W. P., J. N. McCormick, J. R. Goodman, J. M. Yoff ey and H. H. Fudengerg : Peyer's patches: morphologic studies. Cell. Immunol. 1: 500-520 (1971).

Fichtelius, K. E. : The mammalian equivalent to bursa Fabricii of birds. Exp. Cell Res. 46: 231234 (1966).

Good, R. E. and A. E. Gabrielsen : The thymus in immunobiology. Hoeber Medical Division, Harper \& Row, New York-Evanston-London, 1964.

Gowans, J. L. and E. J. Knight: The route of re-circulation of lymphocytes in the rat. Proc. Roy. Soc. Biol. 159: 257-282 (1964).

Greaves, M. F., J. J. T. Owen and M. C. Raff : T and B lymphocytes: origins, properties and role in immune responses. Excepta Medica, American Elsevier, Amsterdam-London, 1973.

Müller-Schoop, J. W. and R. A. Good : Functional studies of Peyer's patches: evidence for their participation in intestinal immune responses. J. Immunol. 114: 1757-1760 (1975).

Owen, R. L.: Sequential uptake of horse radish peroxidase by lymphoid follicle epithelium of Peyer's patches in the normal unobstructed mouse intestine: an ultrastructural study. Gastroenterology 72: 440-451 (1977).

Owen, R. L. and A. L. Jones : Epithelial cell specialization within human Peyer's patches: an ultrastructural study of intestinal lymphoid follicles. Gastroenterology 66: 189-203 (1974).

Perey, D. Y. E. and R. A. Good : Experimental arrest and induction of lymphoid development in intestinal lymphoepithelial tissues of rabbits. Lab. Invest. 18: 15-26 (1968). 
Waksman, B. H., H. Ozer and H. E. Blythman: Appendix and $\gamma$ M-antibody formation. VI. The functional anatomy of the rabbit appendix. Lab. Invest. 28: 614-626 (1973).

阿部和厚

于060 札幌市北区北15条西 7 丁目

北海道大学医学部

解剖学第三講座
Dr. Kazuhiro ABE

Department of Anatomy

Hokkaido University School of Medicine

Sapporo, 060 Japan 